\title{
Effect of Knowledge, Policy, and Supervision on Safety Behavior on Nurses at the Inpatient Installation of Mitra Sejati General Hospital 2021
}

\author{
Wynda Myke Nola Manik ${ }^{1}$, Ida Yustina ${ }^{2}$, Juanita ${ }^{3}$ \\ ${ }^{1,2,3}$ Universitas Sumatera Utara, Indonesia \\ Corresponding Author: Wynda Myke Nola Manik
}

DOI: https://doi.org/10.52403/ijshr.20220116

\begin{abstract}
The purpose of this study is to determine and analyze the effect of knowledge, policy, and supervision on safety behavior on nurses at the Inpatient Installation of Mitra Sejati General Hospital 2021. This research is a quantitative study with a cross sectional study approach and is explanatory research. The number of samples observed in this study were 66 nurses who served in the Inpatient Installation of Mitra Sejati General Hospital. This study uses primary data and secondary data. The data analysis method used bivariate analysis. The results showed that knowledge, policy, and supervision have a significant effect on the safety behavior on nurses at the Inpatient Installation of Mitra Sejati General Hospital 2021.
\end{abstract}

Keywords: Knowledge, Policy, Supervision, Safety Behaviour

\section{INTRODUCTION}

A hospital is a place of work that has a high risk related to the safety and health of hospital human resources, patients, patient companions, visitors, or the hospital environment. Occupational safety and health risks in hospitals can be reduced through the implementation of occupational health and safety in order to create healthy, safe and secure hospital conditions. Occupational safety and health are efforts made to ensure safety and provide an increase in the health status of workers through preventing work-related accidents and occupational diseases, controlling hazards in the workplace, health promotion, treatment and rehabilitation (Peraturan Menteri Kesehatan, 2016).

$88 \%$ of work accidents are caused by unsafe work behavior, such as not wearing personal protective equipment, not following work procedures, not following work safety regulations and working carelessly (Heinrich, 2015). Based on this, it can be said that human behavior is an element that plays an important role in causing an accident, so that an effective way to prevent work accidents is to avoid unsafe behavior.

Accidents due to work and occupational diseases are some of the urgent problems that often occur in the hospital environment. This is because the hospital is a health service unit that provides services in all fields and types of disease. Therefore, hospitals are required to be able to provide and implement an effort so that all human resources in the hospital can be protected, both from illness and work-related accidents (Ivana, 2014).

The International Labor Organization publishes data on the number of workers who die every year, which is 2.78 million due to work accidents and occupational diseases, where occupational diseases cause death of around $86.3 \%$ while fatal work accidents occur more than $13.7 \%$ (International Labor Organization, 2018). Likewise, data recorded at United States hospitals, that an average of $6.8 \%$ of work- 
related injuries or accidents and illnesses for every 100 full-time employees in 2015 (Occupational Safety and Health Administration, 2017).

Data from the National Safety Council in 2013 showed that the occurrence of accidents in hospitals was $41 \%$ greater than workers in other industries. Cases that often occur include needle stick injuries, sprains, back pain, scratches or cuts, burns, infectious diseases and others. In Indonesia, research from Joseph in 2008-2012 noted that the number of needle stick injury accidents reached $38-73 \%$ of the total health workers, where the target for the number of needle stick accidents in every hospital was zero accident (Idayanti, 2015).

In the case of work accidents, the basic solution that is considered the most efficient is to build a culture of occupational safety and health in the work environment by emphasizing safety behavior. Safety behavior can provide certainty to support and always promote accident prevention behavior at all times at work. Safety behavior is a theoretical concept that is widely applied in various industries, health, nuclear, and aviation. Currently, many companies are adopting occupational safety and health performance methods at work.

Safety behavior in the occupational safety and health culture is an integral part of the three aspects of occupational safety and health culture, namely the values of occupational safety and health and the perception of occupational safety and health for each worker, aspects of the occupational safety and health behavior of workers on a daily basis, and also organizational aspects as well as occupational safety and health management in the company. These three aspects interact and are related to each other or cannot stand alone separately. Therefore, occupational safety and health culture cannot be described only by an indicator. Occupational safety and health culture is a concept that concerns the human aspect which has internal aspects that are invisible and external that are visible which of course exist in a social context (Syaaf, 2011).
Several aspects of safety behavior that have a relationship with the implementation of occupational safety and health management in hospitals include knowledge, policies, and supervision. In providing services to patients, nurses must have positive behavior and good knowledge. This attitude and knowledge will encourage nurses to behave in health in accordance with occupational safety and health culture, one of which is by using personal protective equipment when performing their duties (Rifiani, 2013).

The purpose of this study is to determine and analyze the effect of knowledge, policy, and supervision on safety behavior on nurses at the Inpatient Installation of Mitra Sejati General Hospital 2021.

\section{RESEARCH METHODS}

Research methods are steps taken by researchers to collect data or information to be processed and analyzed scientifically (Octiva et al., 2021). Direct observation on the object of study according to the scope of research and theory as a supporter of research based on the scope of the discussion (Octiva et al., 2018). According to Pandia et al. (2018), the purpose of the study is to obtain a formulation of the results of a study through the process of seeking, finding, developing, and testing knowledge.

This research is a quantitative study with a cross sectional study approach and is explanatory research. Quantitative research is an investigation of social problems based on testing a theory consisting of variables, measured by numbers, and analyzed by statistical procedures to determine whether the predictive generalizations of the theory are correct (Pandiangan et al., 2021).

According to Pandiangan (2018), the cross sectional research method is a study to study the dynamics of the correlation between risk factors and effects, by approach, observational, or data collection. Explanatory research is explanatory and aims to test a theory or hypothesis in order 
to strengthen or even reject the existing theory or hypothesis of research results (Pandiangan, 2015).

The population in this study were 66 nurses working in the Inpatient Installation of Mitra Sejati General Hospital in 2021. The consideration of researchers choosing nurses as a population is because they are health workers who interact the most and have the longest contact with patients, especially in Inpatient Installations and are very at risk of having work accidents such as being pricked by a needle while working. The number of samples observed in this study were 66 nurses who served in the Inpatient Installation of Mitra Sejati General Hospital determined by using total sampling.

This study uses primary data and secondary data. Primary data is research variable data collected directly by researchers (Pandiangan et al., 2018). Primary data collection in this study was conducted by conducting interviews and measurements guided by a questionnaire about the application of safety behavior to nurses at the Inpatient Installation of Mitra Sejati General Hospital. Secondary data is data obtained to support research results (Pandiangan et al., 2018). The data of this study were obtained from Mitra Sejati General Hospital.

The data analysis method used bivariate analysis. According to Tobing et al. (2018), bivariate analysis was conducted to determine the relationship between the independent variable and the dependent variable, so that it would be known which independent variable had an effect on the dependent variable with an error tolerance level $(\alpha)$ of $5 \%$ using the chi-square test. If the results of statistical analysis are found ( $p$ $<0.05)$, then the variables are declared to have a significant effect.

\section{RESULT}

\section{Description of Research Site}

Mitra Sejati General Hospital is located at Jalan Besar Abdul HarisNasution No. 7 Pangkalan Mahsyur Village, Medan
Johor Sub district, Medan City, is one of the type $\mathrm{B}$ private hospitals, which provides complete and comprehensive health services, ranging from basic general to subspecialist health services. This hospital was established on October 10, 2001 which at that time was categorized as a type $\mathrm{C}$ hospital with a legal entity as a foundation, namely the Mitra Sejati Foundation. Along with the current development of the hospital, Mitra Sejati General Hospital has been categorized as a type B hospital in accordance with the Hospital Class Determination certificate by the Ministry of Health of the Republic of Indonesia number HK.02.03/I/0992/2013 on 31 May 2013. With the development of government regulations, on May 16, 2013 the legal entity of Mitra Sejati General Hospital which was originally a foundation legal entity namely "Yayasan Mitra Sejati" changed its status to a Limited Liability Company (PT) namely "PT. Mitra SejatiHusada".

\section{Vision, Mission, and Motto}

The formulation of the vision, mission, goals, and motto of Mitra Sejati General Hospital are as follows:

Mitra Sejati General Hospital's vision is to become the first choice hospital in North Sumatra that provides excellent service with orientation to customer needs.

mission is:

Mitra Sejati General Hospital

1. Organizing quality, professional health services by prioritizing patient safety.

2. To make a hospital that is environmentally friendly and creates a sense of security and comfort for patients.

3. Improve facilities, infrastructure and equipment to support service quality.

4. Develop the potential, competence, work ethic and culture of human resources so that they are always ready to face changes and improve the welfare of human resources.

Mitra Sejati General Hospital's motto is "Mitra Anda menujuHidupsehat". 


\section{Type of Health Service}

Mitra Sejati General Hospital has service facilities such as: emergency, outpatient, inpatient, intensive care, maternity (obstetrics) and obstetrics services, operating rooms, hemodialysis, endoscopy, treadmill, echocardiography, ultrasound, radiology, CT Scan, laboratories, medical rehabilitation, nutrition, pharmacy and others.

\section{Bivariate Analysis}

The results of the bivariate analysis between the influence of knowledge, policies, and supervision with safety behavior can be seen in the Table below:

Table1. Bivariate Test Results of Knowledge with Safety Behavior

\begin{tabular}{|c|c|c|c|c|c|c|c|}
\hline \multirow{2}{*}{ Knowledge } & \multicolumn{3}{|c|}{ Safety Behaviour } & \multicolumn{2}{c|}{ Total } & \multirow{2}{*}{$\begin{array}{c}\text { p } \\
\text { value }\end{array}$} \\
\cline { 2 - 6 } & Not Good & \multicolumn{2}{|c|}{ Good } & \multicolumn{2}{c|}{} \\
\cline { 2 - 6 } & $\mathbf{n}$ & $\%$ & $\mathbf{n}$ & $\%$ & n (66) & $\%$ & \\
\hline \multirow{2}{*}{$\begin{array}{c}\text { Not Good } \\
\text { Good }\end{array}$} & 12 & 60.0 & 8 & 40.0 & 20 & 100.0 & 0.001 \\
\cline { 2 - 6 } & 1 & 2.2 & 45 & 97.8 & 46 & 100.0 & \\
\hline
\end{tabular}

Table2. Bivariate Test Results of Supervision with Safety Behavior

\begin{tabular}{|c|c|c|c|c|c|c|c|}
\hline \multirow{3}{*}{ Policy } & \multicolumn{3}{|c|}{ Safety Behaviour } & \multicolumn{2}{c|}{ Total } & \multirow{2}{*}{$\begin{array}{c}\text { p } \\
\text { value }\end{array}$} \\
\cline { 2 - 6 } & Not Good & \multicolumn{2}{|c|}{ Good } & \multicolumn{2}{c|}{} \\
\cline { 2 - 6 } & $\mathbf{n}$ & $\mathbf{\%}$ & $\mathbf{n}$ & $\mathbf{\%}$ & $\mathbf{n}(\mathbf{6 6})$ & \% & \\
\hline \multirow{2}{*}{$\begin{array}{c}\text { Not Good } \\
\text { Good }\end{array}$} & 10 & 55.6 & 8 & 44.4 & 18 & 100.0 & 0.030 \\
\cline { 2 - 7 } & 3 & 6.3 & 45 & 93.8 & 48 & 100.0 & \\
\hline
\end{tabular}

Table3. Bivariate Test Results of Supervision with Safety Behavior

\begin{tabular}{|c|c|c|c|c|c|c|c|}
\hline \multirow{2}{*}{ Supervision } & \multicolumn{3}{|c|}{ Safety Behaviour } & \multicolumn{3}{c|}{ Total } & \multirow{2}{*}{ p value } \\
\cline { 2 - 6 } & Not Good & \multicolumn{2}{|c|}{ Good } & \multicolumn{2}{|c|}{} \\
\cline { 2 - 6 } & $\mathbf{n}$ & \% & n & \% & n (66) & \% & \\
\hline \multirow{2}{*}{$\begin{array}{c}\text { Not Good } \\
\text { Good }\end{array}$} & 11 & 44.0 & 14 & 56.0 & 25 & 100.0 & 0.001 \\
\cline { 2 - 6 } & 2 & 4.9 & 39 & 95.1 & 41 & 100.0 & \\
\hline
\end{tabular}

The results showed that knowledge, policy, and supervision have a significant effect on the safety behavior on nurses at the Inpatient Installation of Mitra Sejati General Hospital 2021.

\section{CONCLUSION AND SUGGESTION}

The results showed that knowledge, policy, and supervision have a significant effect on the safety behavior on nurses at the Inpatient Installation of Mitra Sejati General Hospital 2021.

The suggestions in the research are for hospital management to further improve supervision of safety behavior in hospitals, and be carried out in a sustainable manner so that the level of compliance of all nurses to implement regulations or provisions on safety behavior increases. The head of the room as the person in charge of supervision is expected to be able to provide strict sanctions for nurses who do not use personal protective equipment when taking action.

\section{Acknowledgement: None}

\section{Conflict of Interest: None}

Source of Funding: None
Ethical Approval: Approved

\section{REFERENCES}

1. Heinrich, H. W. (2015). Industrial Accident Prevention, a Safety Management Approach. MCGraw Hill Book Company.

2. Idayanti. (2015). HubunganPengetahuan dan SikapPerawatTerhadapPenerapan StandarOperasionalProsedur Kesehatan Lainnya. Jakarta: Departemen Kesehatan (SOP) Teknik Menyuntikdalam Upaya Pencegahan RI.

3. International Labour Organization. (2018). Data on the Number of Workers who Died.

4. Ivana, A. (2014). Analisa Komitmen Manajemen RumahSakit (RS) Terhadap Keselamatan dan Kesehatan Kerja (K3) pada RS Prima MedikaPemalang.Jurnal Kesehatan Masyarakat.

5. Occupational Safety and Health Administration. (2017). Caring for Our Caregivers-Facts about Hospital Worker Safety. Amerika: USA Departemen of Labour.

6. Octiva, C. S., Irvan, Sarah, M., Trisakti, B., \& Daimon, H. (2018). Production of Biogas from Co-digestion of Empty Fruit Bunches (EFB) with Palm Oil Mill Effluent (POME): Effect of Mixing Ratio. Rasayan J. Chem., 11(2), 791-797.

7. Octiva, Cut Susan, Indriyani, \& Santoso, Ari Beni. (2021). Effect of Stirring Codigestion of Palm Oil and Fruith for Biogas 
Production to Increase Economy Benefit. Budapest International Research and Critics Institute-Journal, 4(4), 1415214160. https://doi.org/10.33258/birci.v4i4.3521.

8. Pandia, S., Tanata, S., Rachel, M., Octiva, C., \&Sialagan, N. (2018). Effect of Fermentation Time of Mixture of Solid and Liquid Wastes from Tapioca Industry to Percentage Reduction of TSS (Total Suspended Solids). IOP Conference Series: Materials Science and Engineering, 309, 012086. DOI: 10.1088/1757-899X/309/1/ 012086.

9. Pandiangan, Saut Maruli Tua. (2015). Analisis Lama Mencari Kerja Bagi Tenaga Kerja Terdidik di Kota Medan. Skripsi. Medan: Fakultas Ekonomi dan Bisnis, Program Studi Ekonomi Pembangunan, Universitas Sumatera Utara. https://www.academia.edu/52494724/Analis is_Lama_Mencari_Kerja_Bagi_Tenaga_Ker ja_Terdidik_di_Kota_Medan.

10. Pandiangan, Saut Maruli Tua. (2018). Analisis Faktor-faktor yang Mempengaruhi Penawaran Tenaga Kerja Lanjut Usia di Kota Medan. Tesis. Medan: Fakultas Ekonomi dan Bisnis, Program Studi Ilmu Ekonomi, Universitas Sumatera Utara. http://repositori.usu.ac.id/bitstream/handle/1 23456789/10033/167018013.pdf?sequence= $1 \&$ isAllowed $=\mathrm{y}$.

11. Pandiangan, Saut Maruli Tua, Rujiman, Rahmanta, Tanjung, Indra I., Darus, Muhammad Dhio, \& Ismawan, Agus. (2018). An Analysis on the Factors which Influence Offering the Elderly as Workers in Medan. IOSR Journal of Humanities and Social Science (IOSR-JHSS), 23(10), 76-79. DOI: $10.9790 / 0837-2310087679$.

12. Pandiangan, Saut Maruli Tua, Resmawa, Ira Ningrum, Simanjuntak, Owen De Pinto,
Sitompul, Pretty Naomi, \& Jefri, Riny. (2021). Effect of E-Satisfaction on Repurchase Intention in Shopee User Students. Budapest International Research and Critics Institute-Journal, 4(4), 77857791. DOI: https://doi.org/10.33258/birci.v4i4.2697.

13. Peraturan Menteri Kesehatan.(2016). Keselamatan dan Kesehatan Kerja Rumah Sakit. Jakarta: Menteri Kesehatan RI.

14. Rifiani, N. (2013). Prinsip-prinsip Dasar Keperawatan. Cetakan 1. Jakarta: Dunia Cerdas.

15. Syaaf, Ridwan. (2011). Implementasi Program Pengembangan Budaya K3 di Tempat Kerja. Jurnal Kesehatan Kerja. Accessed https://docplayer.info/72056188Implementasi-program-pengembanganbudaya-k3-di-tempat-kerja-ridwan-zsyaaf.html.

16. Tobing, Murniati, Afifuddin, Sya'ad, Rahmanta, Huber, Sandra Rouli, Pandiangan, Saut Maruli Tua, \& Muda, Iskandar. (2018). An Analysis on the Factors Which Influence the Earnings of Micro and Small Business: Case at Blacksmith Metal Industry. Academic Journal of Economic Studies, 5(1), 17-23. https://www.ceeol.com/search/articledetail $? \mathrm{id}=754945$.

How to cite this article: Wynda Myke Nola Manik, Ida Yustina, Juanita. Effect of knowledge, policy, and supervision on safety behavior on nurses at the inpatient installation of Mitra Sejati General Hospital 2021. International Journal of Science \& Healthcare Research. 2022; 7(1): 94-98. DOI: https:// doi.org/10.52403/ijshr.20220116 